DOI: https://doi.org/10.31933/dijemss.v2i2

Received: $30^{\text {th }}$ July 2020, Revised: $25^{\text {th }}$ October 2020, Publish: $20^{\text {th }}$ December 2020

$\begin{array}{ll}\text { DIJEMSS } & \\ \text { DINASTI INTERNATIONAL JOURNAL } & \text { https://dinastipub.org/DIJEMSS } \\ \text { editor@dinastipub.org } & 08117401455 @\end{array}$

\title{
UTILITARIAN VALUES AND HEDONIC VALUES OF WOMEN COFFEE LOVERS
}

\author{
Hamdan Hamdan ${ }^{1}$, Paijan Paijan ${ }^{2}$ \\ 1) Universitas Mercu Buana, Jakarta, Indonesia, hamdan@ mercubuana.ac.id \\ 2) Universitas Mercu Buana, Jakarta, Indonesia, paijan@ mercubuana.ac.id
}

Corresponding Author: Hamdan Hamdan

Abstract: This study on the utilitarian values and hedonic values for women coffee lovers, aims to analyze the role of product attributes to the utilitarian values and hedonic values in shaping positive attitudes and behavior of consumers in deciding the purchase intentions. The design of this study uses descriptive-quantitative research. While the determination of the sample is women's in West Jakarta who have consumed coffee today by using purposive sampling techniques to 148 women. The results of primary data collection will be analyzed using the SEM-Covariance method. The findings of this study indicate that product attributes have a positive and significant effect on utilitarian values and hedonic values. The utilitarian values and hedonic values have a positive significant effect on repurchase intention.

Keywords: coffee, hedonic values, utilitarian values, women.

\section{INTRODUCTION}

The growth of coffee shop business contributes a big role in increasing coffee consumption. Indonesian people's coffee drinking patterns, both men and women, consist of productive age. The trend of drinking coffee is now not only dominated and favored by men, but has become the lifestyle of women (Latif, 2019). In fact (Analisadaily.com, 2019), not a few millennial generation women as coffee connoisseurs.

Coffee has become a representation of a woman's lifestyle, (Agrawal et al., 2013) because the purpose of consuming drinks is for health and pleasure. Millennial women's positive response to coffee consumption, making coffee shop businesses more creative and innovative in developing appropriate and effective business strategies, because the coffee market is becoming more competitive (Gurusamy \& Yamakanith, 2015), in understanding consumer behavior. Rekarti \& Doktoralina, (2017) it is important to make competitors as an orientation measure so as not to lose future competition.

Competitive advantage can be achieved when consumers realized value (Woodruff, 1997) and clarity of strategy is a key determinant of effective and appropriate decision making (Permana, 2017). Some trends and concepts of coffee today, such as coffee shops, (Aw et al., 2019) not only offer food and drinks, but rather provide a comfortable atmosphere. The focus of today's coffee 
shops is on service quality, product quality and atmosphere quality to build perceived value (Susanty \& Kenny, 2015; Ting \& Thurasamy, 2016).

Repurchase intention has been widely studied by previous researchers including (Ali, 2019; Firmansyah \& Ali, 2019; Larasetiati \& Ali, 2019; Lin et al., 2011; Pramatatya et al., 2004; Wang \& Yu, 2016). Research by (Tasurru \& Salehudin, 2014) repurchase intention is influenced by various factors, such as product attributes (Aertsens et al., 2011; Chen \& Sun, 2014; Jianying et al., 2014; Lee \& Liao, 2009; Mueller Loose \& Szolnoki, 2012), utilitarian values (Gan \& Wang, 2017; Josephmathews et al., 2009; Park, 2004; Vijaranakorn \& Shannon, 2017; Wang \& Yu, 2016) and hedonic values (Kazakevičiūtė \& Banytė, 2013; Mueller Loose \& Szolnoki, 2012; Vijaranakorn \& Shannon, 2017; Wang \& Yu, 2016).

Coffee variants are more varied and there are many flavors of coffee beans, ranging from Aceh Gayo Coffee to Papua Wamena Coffee with various other flavors. So it is not surprising that not only young and old men, but also many young women who consume and like coffee. The taste and atmosphere of a coffee shop (Murphy \& Jenner-Leuthart, 2011) have an important influence on repurchase intention (Tasurru \& Salehudin, 2014).

Today's coffee also offers a variety of latte art that gives character and uniqueness in adding an attractive impression to women who enjoy coffee. Besides the place, the varied taste of coffee, latte art, design and packaging give an attractive impression for women in enjoying coffee. An important factor for shaping consumer behavior is perceived value (Chen \& Sun, 2014; Gupta et al., 2011).

Perceived value is used to predict consumer behavior (Gould-Williams, 1999), because product attributes have an important role to the value perceived by consumers (Chiu et al., 2019). Perceived values can investigate the perspective of utilitarian and hedonic values (Babin et al., 1994; Wang \& Yu, 2016). Hedonic values are based on positive emotional responses experienced by consumers when using a product (Schollenberg, 2012).

The hedonic value perception reflects shopping experiences related to pleasure, and fantasies felt by consumers (Scarpi, 2006). Whereas the perceived utilitarian value's determined through product evaluation according to its functional characteristics (Chuang et al., 2013; Park, 2004). Where functional characteristics are influenced by packaging, (Loose \& Szolnoki, 2012), including capacity, color, shape, typography, and brand names (Lee \& Liao, 2009; Sorenson \& Bogue, 2006; Wang, 2015).

The trend of drinking coffee is now not only dominated and favored by men, but has become a representation of women's lifestyle. Shifting the lifestyle of millennials, especially women, will be oriented towards perceived values. Because anything that creates a modern impression tends to be consumed and a willingness to buy back on an ongoing basis. Especially with the increasing number of coffee shop businesses that carry a comfortable atmosphere with unique interior and exterior designs, the varied flavors of coffee, and the latte art that give a positive impression and a strong character in shaping consumer value. Perceived value is a functional and emotional response when consumers consume coffee.

Researchers propose an important theme to analyze, namely the effect of product attributes on utilitarian value and hedonic value in forming repurchase intention in women who enjoy coffee. Thus, the formulations of this study are: 1) analysis of the product attributes positive significant effect on the value of women utilitarian coffee lovers; 2) analysis of the product attributes positive significant effect on the hedonic value women coffee drinkers; 3) analysis of the utilitarian value 
positive significant effect on the woman's repurchase intention coffee lovers; 4) analysis of the hedonic value positive significant effect on the woman's repurchase intention coffee lovers.

This research is expected to contribute both practically and theoretically. Practical contributions are expected to benefit business actors in formulating business models and provide relevant information in creating creative and innovative ideas so that they become more competitive and business continuity in the future. While the theoretical contribution, namely contributing to science in the future, especially in the field of management science. The novelty of this study is to analyze the trends of coffee lovers who are respondents in this study. It is known that coffee lovers today, not only for men but has become part of the millennial lifestyle of women. The perceived value of consumers when consuming coffee will be seen from the factor of how often or the intention to behave to repurchase is influenced by product attributes, utilitarian value and hedonic values.

\section{LITERATURE REVIEW}

\section{Effect of Product Attributes on Utilitarian Value}

Utilitarian value reflects the overall assessment of functional benefits including excellent service, time savings, price savings and several other physical attributes of the product (Wang \& Yu, 2016). The perceived utilitarian value can be evaluated according to their functional characteristics (Chuang et al., 2013; Park, 2004). Product attributes both intrinsic and extrinsic concern product characteristics such as packaging color and serving size (Bernués et al., 2003), coffee taste, flavor and coffee shop atmosphere (Murphy \& Jenner-Leuthart, 2011), affecting consumers' perceptions of value for product offerings. (Munnukka \& Järvi, 2012).

Marketers can identify why consumers buy products by categorizing product attributes as perceived value (Jianying et al., 2014). The perceived functional attributes can improve consumer image and decide to make a purchase (Aertsens et al., 2011). Product packaging can provide a perceived functional and experiential benefit to the product (Chen \& Sun, 2014). Consumer preferences are strongly influenced by packaging (Mueller Loose \& Szolnoki, 2012), such as size, color, shape, typography, and brand names (Lee \& Liao, 2009; Sorenson \& Bogue, 2006; Wang, 2013). Previous findings prove that product packaging affects consumer decisions according to the expected price (Van den Heuvel et al., 2011). From the results of the review of previous research, it can be proposed a research hypothesis, that:

H-1: Product attributes have a positive significant effect on utilitarian value

\section{Effect of Product Attributes on Hedonic Value}

The hedonic value is determined by the taste and flavor attributes (Park, 2004; Weafer et al., 2014). Basically, product quality such as taste or sweetness is associated with hedonic responses (Drichoutis et al., 2006; Yoon Kin Tong et al., 2012). Hedonic value represents an emotional response associated with product consumption (Park, 2004; Schollenberg, 2012), which reflects the pleasure, enjoy, happiness and fantasies that consumers perceive (Scarpi, 2006). Typically, taste offers satisfaction (Drichoutis et al., 2006), and sweetness is associated with hedonic responses (Yoon Kin Tong et al., 2012). So that product packaging has emotional value for consumers (Grundey, 2010), which can provide a sense of pleasure and benefit from attractive packaging (Underwood, 2003). From the results of the review of previous research, the next hypothesis can be proposed, that:

H-2: Product attributes have a positive significant effect on hedonic value.

\section{The Effect of Utilitarian Value and Hedonic Value on Repurchase Intention}


Repurchase intention refers to the desire of consumers to repurchase certain products in the future (Barber et al., 2013; Kelley et al., 2015). Research developed by (Joseph-mathews et al., 2009; Torlak et al., 2019) states that perceived value significantly influences purchase behavior intentions. As well as research by (Chiu et al., 2019; Topaloğlu, 2012) states that perceptions of utilitarian value and hed onic value influence consumer behavioral intentions. Meanwhile (Park, 2004; Wang \& Yu, 2016) shows that consumer repurchase intentions can be predicted based on the perception of utilitarian value and hed onic value. Ryu et al. (2010) increase customer perceptions of hedonic and utilitarian values in ensuring satisfaction, so that it can influence positive behavioral emotions for returning visits. From the results of the research review, the next hypothesis can be proposed, that: H-3: Utilitarian value has a positive significant effect on repurchase intention.

H-4: Hedonic value has a positive significant effect on repurchase intention.

Based on the results of a review of previous research studies, a conceptual framework can be built, namely the effect of product attributes on utilitarian and hedonic values in shaping the repurchase intention of women who enjoy coffee, shown in Figure 1 below.

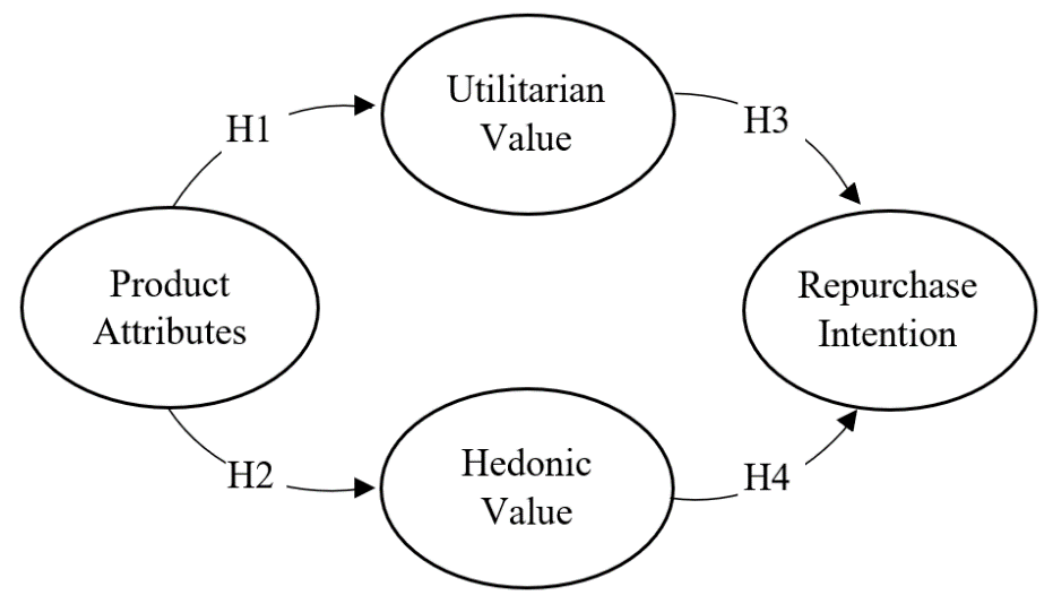

Figure 1. Conceptual Framework

\section{RESEARCH METHODS}

This research design is descriptive quantitative research. Shields and Rangarajan (2013) used descriptive research to describe phenomena as descriptive categories. Shuttleworth (2008) defines quantitative research design as the best way to prove hypotheses, (Babbie, 2010) by using objective measurements and statistical analysis obtained through questionnaires to explain certain phenomena.

The population of this research is women who enjoy coffee in West Jakarta. Hair et al. (2010) assumed SEM for the sample to be processed must be greater than 100. On this basis, 148 samples were used. The selection of West Jakarta women as a sample used a pursposive sampling technique (selecting respondents based on their abilities) (Robinson, 2014). The criteria for respondents were women who had made purchases of contemporary coffee. Respondents attitudes towards questionnaire items were measured using a 7-point scale, because (Preston \& Colman, 2000) using a 7-point scale has good reliability, validity and strength of discrimination.

Data analysis techniques using Structural Equation Modeling-Covariance with a measurement model CFA. SEM-Covariance is evaluated through: overall model fit (absolute match size, incremental match size and parsimony match size), measurement model match (with criteria if the 
factor $t$ value $\geq 0,50$ can be said to be valid and the construct has good reliability, if the Construct Reliability value $\geq 0,70$ and the value of Average Variance Extracted $\geq 0,50$ ), and structural compatibility (testing the relationship between variables, whether it has a positive or negative coefficient and t-statistic $\geq 1,96$.

SEM-Covariance is an analysis method with the measurement model Confirmatory Fact or Analysis (CFA) which evaluates the suitability of the data with the model through three stages (Hair et al., 2010). The first stage, overall model fit, is evaluated through the degree of fit (GOF). The GOF measure has three measures, including: a) absolute fit measures; b) incremental fit measures; and c) parsimony fit measures. The second stage, measurement fit model, is evaluated through indicator items, where the indicator items have conditions, if the loading factor $\geq 0,50$ is declared valid and the construct has good reliability, if Construct Reliability $(\mathrm{CR} \geq 0,70)$ and Variance Extracted $(A V E \geq 0,50))$. The third stage is structural model fit, where the evaluation of this model is through testing the influence between variables on the condition that the path coefficient value is positive and if the t-statistic value $\geq 1,96$ is declared to have a significant effect.

\section{FINDINGS AND DISCUSSION \\ Overall Model Fit}

The results of the overall model fit test were evaluated through: a) absolute fit measures, the GFI value $=0,84 \leq 0,90$ and the RMSEA value $=0,076 \leq 0,08$; $\mathrm{b}$ ) the measure of incremental suitability, the NFI value is obtained $=0,96 \geq 0,90$; NNFI $=0.97 \geq 0,90 ; \mathrm{CFI}=0,98 \geq 0,90 ; \mathrm{IFI}=0,98$ $\geq 0,90$; and RFI $=0,95 \geq 0,90$; and c) the measure of parsimony suitability, obtained the value of AGFI $=0,78 \leq 0,90$ and PGFI $=0,59 \geq 0,50$. Some of the match results have not met the Goodness of Fit (GOF) criteria, such as GFI and AGFI. However, the model built is still said to be good, because it is at the level of good test criteria.

\section{Measurement Model Fit}

The measurement model fit test aims to determine the contribution of each indicator in measuring the latent variable. The criteria used if lambda $\geq 0,50$ is declared valid and $\leq 0,50$ is declared invalid. For the criteria for the construct reliability value $\geq 0,70$, and the average variance value $\geq 0,50$. The results of the suitability of the measurement model can be seen in Table 1 below. 
Table 1. Measurement Model Fit Results

\begin{tabular}{|c|c|c|c|c|}
\hline Latent Construct & Lambda & Erorr & $\begin{array}{l}\text { Construct } \\
\text { Reliability }\end{array}$ & $\begin{array}{l}\text { Average } \\
\text { Variance }\end{array}$ \\
\hline $\begin{array}{l}\text { Product attribute: } \\
\text { - Coffee quality } \\
\text { - Shop concept } \\
\text { - Shop atmosphere } \\
\text { - Coffee texture } \\
\text { - Taste and flavor of coffee } \\
\text { - Coffee color and packaging } \\
\text { - Coffee shop name and brand } \\
\text { - Method of serving coffee }\end{array}$ & $\begin{array}{l}0.75 \\
0.80 \\
0.78 \\
0.86 \\
0.84 \\
0.82 \\
0.75 \\
0.82 \\
\end{array}$ & $\begin{array}{l}0.44 \\
0.37 \\
0.39 \\
0.26 \\
0.30 \\
0.33 \\
0.43 \\
0.33 \\
\end{array}$ & 0.935 & 0.644 \\
\hline $\begin{array}{l}\text { Utilitarian value: } \\
\text { - Coffee prices according to benefits } \\
\text { - Coffee prices according to ability } \\
\text { - Benefits of relieving sleepiness } \\
\text { - Positive caffeine content }\end{array}$ & $\begin{array}{l}0.73 \\
0.66 \\
0.53 \\
0.58\end{array}$ & $\begin{array}{l}0.47 \\
0.57 \\
0.72 \\
0.66\end{array}$ & 0.720 & 0.396 \\
\hline $\begin{array}{l}\text { Hedonic Value: } \\
\text { - Better thoughts } \\
\text { - Happiness } \\
\text { - Atmosphere comfortable and relaxed } \\
\text { - Texture and latte art }\end{array}$ & $\begin{array}{l}0.81 \\
0.97 \\
0.86 \\
0.69\end{array}$ & $\begin{array}{l}0.34 \\
0.05 \\
0.25 \\
0.52\end{array}$ & 0.905 & 0.708 \\
\hline $\begin{array}{l}\text { Repurchase intention: } \\
\text { - Consideration to repurchase } \\
\text { - Possibility to repurchase } \\
\text { - Willingness to repurchase } \\
\text { - Consider repurchase in the future }\end{array}$ & $\begin{array}{l}0.51 \\
0.89 \\
0.91 \\
0.72\end{array}$ & $\begin{array}{l}0.74 \\
0.20 \\
0.18 \\
0.48\end{array}$ & 0.851 & 0.568 \\
\hline
\end{tabular}

Source: Lisrel Data Process Results

Based on the measurement model in above, it shows that all loading factors of the product attribute indicator, utilitarian value, hedonic value and repurchase intention are valid, because the contribution of product attribute indicators, such as: coffee quality, shop concept, shop atmosphere, coffee texture, taste and coffee flavor, coffee color and packaging, the name and brand of the coffee shop, and the method of serving coffee have a lambda value of above 0.50 . The contribution of utilitarian value indicators includes: the price of coffee according to benefits, the price of coffee according to ability, the benefits of relieving sleepiness, and the positive caffeine content having a lambda value of above 0.50 . The contribution of hed onic value indicators such as: making the mind better, feeling happy, a comfortable and relaxed atmosphere, and texture and latte art having a lambda value above 0.50. And the contribution of the repurchase intention indicator which such as: consideration of repurchasing, the possibility of repurchasing and consideration of buying back in the future has a lambda value above 0.05 . Thus, the contribution of each indicator in measuring the latent variables built has met the criteria at the good test level. 
The results of all $\mathrm{CR}$ values of product attributes, utilitarian value, hedonic value and repurchase intention were above 0.70 . This means that indicator items in measuring latent variables (product attributes, utilitarian value, hedonic value and repurchase intention) have good reliability. The AV value of the product attributes, hedonic value and repurchase intention are above 0.50, unless the utilitarian value is below 0.50. This means that the indicator items have a good diversity in measuring latent variables such as: product attributes, hedonic value and repurchase intention.

\section{Structural Model Fit}

The structural models of fit aims to determine the results of testing the coefficients and $\mathrm{t}$ statistics between variables. The relationship of each variable to the conceptual model built is shown in Figure 2 below.

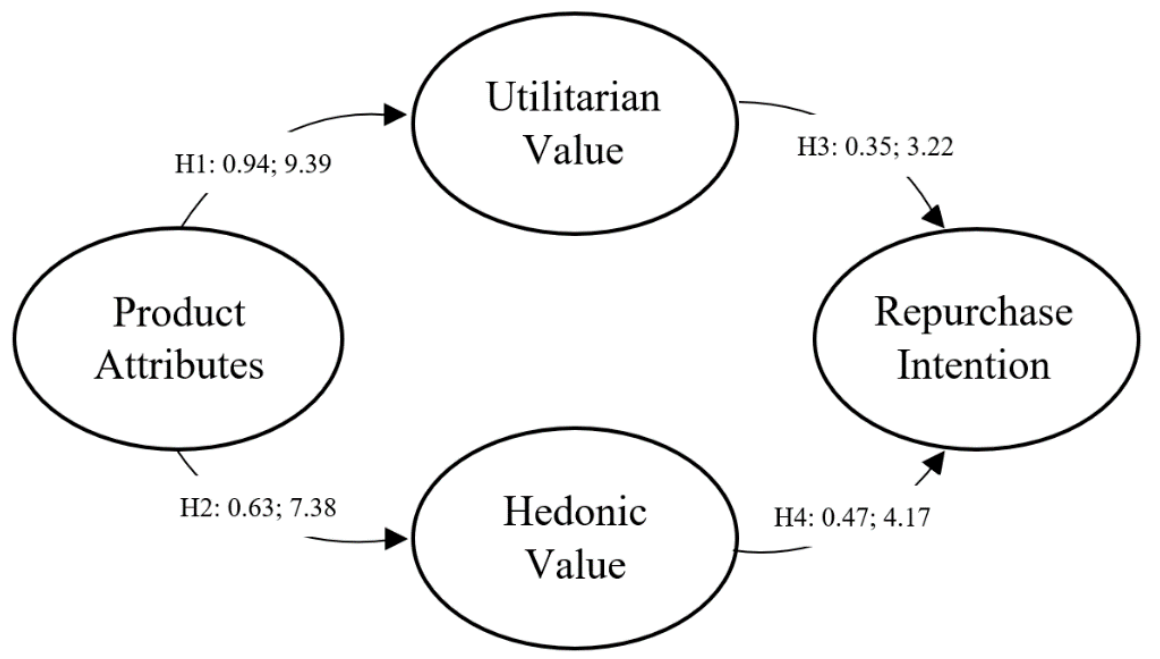

Figure 2. Structural Model Results

\section{Product attributes influences utilitarian value}

The results of the structural model in the first hypothesis (H1) state that product attributes have a positive significant effect on utilitarian value. Based on testing using SEM-Covariance, the product attribute has a positive significant effect with the utilitarian value (path coefficient $=0.94$; $\mathrm{t}$-statistic =9.39). The correlation coefficient between product attributes and utilitarian value is 0.94. That is, if the perceived product attributes have increased, it will affect the level of women's utilitarian value towards coffee today. The results of this study are the same as research developed by (Murphy \& Jenner-Leuthart, 2011; Munnukka \& Järvi, 2012; Jianying et al., 2014; Aertsens et al., 2011) which states that product attributes have a positive significant effect on utilitarian value.

\section{Product attributes influences hedonic value}

The results of the structural model in the second hypothesis $(\mathrm{H} 2)$ state that product attributes have a positive significant effect on hedonic value. Based on testing using SEM-Covariance, product attributes have a positive significant effect with hedonic values (path coefficient $=0.63$; $\mathrm{t}$-statistic $=$ 7.38). The magnitude of the correlation coefficient between product attributes and hedonic value is 0.63 . That is, if the perceived product attributes have increased, it will affect the level of hed onic value of women towards coffee today. The results of this study are the same as research developed by (Park, 2004; Weafer et al., 2014; Drichoutis et al., 2006; Yoon Kin Tong et al., 2012; Schollenberg, 2012) which states that product attributes have a positive significant influence with hedonic value. 


\section{Utilitarian value influences repurchase intention}

The results of the structural model in the third hypothesis (H3) state that utilitarian value has a positive significant effect on repurchase intention. Based on the SEM-Covariance test, the utilitarian value has a positive significant effect on repurchase intention (path coefficient $=0.35$; $\mathrm{t}$-statistic $=$ 3.22). The magnitude of the correlation coefficient between utilitarian value and repurchase intention is 0.35 . That is, if the perceived utilitarian value is in accordance with the benefits received, it will lead to a positive attitude for women to make repeated purchases of coffee today. The results of this study are the same as research developed by (Barber et al., 2013; Kelley et al., 2015; Chiu et al., 2019; Topaloğlu, 2012) which states that utilitarian value has a positive significant effect by asking for repurchase.

\section{Hedonic value influences repurchase intention}

The results of the structural model in the fourth hypothesis $(\mathrm{H} 4)$ state that the hedonic value has a positive significant effect on repurchase intention. Based on the SEM-Covariance test, the hedonic value has a positive significant effect on repurchase intention (path coefficient $=0.47$; $\mathrm{t}$ statistic $=4.17$ ). The magnitude of the correlation coefficient between hedonic value and repurchase intention is 0.47 . That is, if the perceived hedonic value is in accordance with the lifestyle, it will form a positive attitude for women to make repeated purchases of today's coffee. The results of this study are the same as research developed by (Chiu et al., 2019; Topaloğlu, 2012; Wang \& Yu, 2016; Ryu et al. 2010), which implies that hedonic value has a positive significant effect on repurchase intention.

\section{CONCLUSION AND RECOMMENDATION Conclusion}

The results of the analysis of the utilitarian value and the hedonic value of women's who drink coffee by using the analysis of the measurement model of each factor and the suitability of the overall model, show that the model being tested is a good model at the level of good and acceptable test criteria. Based on the formulation and research objectives built, it can be stated that the findings in this study include: 1) the product attributes positive significant effect on the value of women utilitarian of coffee lovers; 2) the product attributes positive significant effect on the hedonic value women of coffee lovers; 3 ) the utilitarian value positive significant effect on the woman repurchase intention of coffee lovers; 4) the hedonic value positive significant effect on the woman repurchase intention of coffee lovers.

\section{Recommendation}

The suggestion given to stakeholders in the academic field is to add more research samples, especially women who enjoy coffee. This is because consuming coffee is part of a woman's lifestyle and to know more about women's characteristics when consuming coffee. It is also necessary to add social, cultural or subcultural influences, and lifestyle factors when conducting further research. While suggestions for business people should pay attention to aspects, including: coffee quality, shop concept, shop atmosphere, coffee texture, coffee taste and flavor, coffee color and packaging, coffee shop name and brand, method of serving coffee, coffee prices according to benefits, price of coffee according to ability, benefits of relieving sleepiness, positive caffeine content, a better mind, feeling happy, comfortable and relaxed, texture and latte art. This can give rise to considerations of 
repurchasing, possible repurchase, willingness to repurchase and considerations of repurchasing at a future date.

\section{REFERENCE}

Aertsens, J., Mondelaers, K., Verbeke, W., \& Buysse, J. (2011). The influence of subjective and objective knowledge on attitude, motivations and consumption of organic food. https://doi.org/10.1108/00070701111179988

Agrawal, G. K., Timperio, A. M., Zolla, L., Bansal, V., Shukla, R., \& Rakwal, R. (2013). Biomarker discovery and applications for foods and beverages: Proteomics to nanoproteomics. Journal of Proteomics, 93, 74-92. https://doi.org/10.1016/j.jprot.2013.04.014

Ali, H. (2019). Building Repurchase Intention and Purchase Decision: Brand Awareness and Brand Loyalty Analysis (Case Study Private Label Product in Alfamidi Tangerang). Saudi Journal of $\begin{array}{llll}H & \text { Humanities } & \text { Social } & \text { 64iences, }\end{array}$ https://doi.org/10.36348/sjhss.2019.v04i09.009

Aw, E. C. X., Flynn, L. R., \& Chong, H. X. (2019). Antecedents and consequences of self-congruity: replication and extension. Journal of Consumer Marketing, 36(1), 102-112. https://doi.org/10.1108/JCM-10-2017-2424

Babbie, E.R. (2010). The Practice of Social Research. London: Cengage Learning.

Babin, B. J., Darden, W. R., \& Griffin, M. (1994). Utilitarian shopping value. Journal of Consumer Research, 20(4), 644-657. https://doi.org/DOI: http://dx.doi.org/10.1086/209376

Bernués, A., Olaizola, A., \& Corcoran, K. (2003). Extrinsic attributes of red meat as indicators of quality in Europe: An application for market segmentation. Food Quality and Preference, 14(4), 265-276. https://doi.org/10.1016/S0950-3293(02)00085-X

Chen, H. J., \& Sun, T. H. (2014). Clarifying the impact of product scarcity and perceived uniqueness in buyers' purchase behavior of games of limited-amount version. Asia Pacific Journal of Marketing and Logistics, 26(2), 232-249. https://doi.org/10.1108/APJML-07-2013-0084

Chiu, C.-H., Wei, S.-T., Wei, C.-S., \& Wei, C.-C. (2019). Impact of eight dimensions on the business of specialty coffee shop. Pressacademia, 6(1), 79-87. https://doi.org/10.17261/pressacademia.2019.1023

Chuang, F.-Y., Lee, L.-Y., \& Li, L.-Y. (2013). Canonical Correlation Analysis-Examining the Relationship between Consumption Experience and Experiential Value. Journal of International Management Studies, 8(2), 95-102. http://search.proquest.com/d ocview/1459224770?accountid=46437 
Drichoutis, A., Lazaridis, P., \& Nayga Jr, R. (2006). Consumers' use of nutritional labels: a review of research studies and issues. Academy of Marketing Science Review, 2006(9), 1.

Firmansyah, N., \& Ali, H. (2019). Consumer Trust Model: The Impact of Satisfaction and E-Service Quality toward Repurchase Intention in E-Commerce. 6256, 552-559. https://doi.org/10.21276/sjhss.2019.4.8.4

Gan, C., \& Wang, W. (2017). The influence of perceived value on purchase intention in social commerce context. Internet Research, 27(4), 772-785. https://doi.org/10.1108/IntR-06-20160164

Gould-Williams, J. (1999). The impact of employee performance cues on guest loyalty, perceived value and service quality. Service Industries Journal, 19(3), 97-118. https://doi.org/10.1080/02642069900000032

Grundey, D. (2010). Functionality of product packaging: Surveying consumers' attitude towards selected cosmetic brands. Economics and Sociology, 3(1), 87-103. https://doi.org/10.14254/2071-789X.2010/3-1/9

Gupta, S., Kim, H. W., \& Sharma, M. (2011). Customer switching to organized retail in semiurban markets: A study in an Indian context. Journal of International Consumer Marketing, 23(5), 314328. https://d oi.org/10.1080/08961530.2011.602950

Gurusamy, P., \& Yamakanith, P. (2015). Export performance of coffee in India- An analytical study. 2(2), 118-122.

Hofmans, J., Theuns, P., \& Mairesse, O. (2007). Impact of the number of response categories on linearity and sensitivity of self-anchoring scales: A functional measurement approach. Methodology, 3(4), 160-169. https://doi.org/10.1027/1614-2241.3.4.160

Jianying, F., Xia, W., Zetian, F., \& Weisong, M. (2014). Assessment of consumers' perception and cognition toward table grape consumption in China. British Food Journal, 116(4), 611-628. https://doi.org/10.1108/BFJ-04-2012-0101

Joseph-mathews, S., Bonn, M. A., \& Snepenger, D. (2009). Atmospherics and consumers' symbolic interpretations of hedonic services. International Journal of Culture, Tourism and Hospitality Research, 3(3), 193-210. https://doi.org/10.1108/17506180910980519

Kazakevičiūtè, A., \& Banytė, J. (2013). The Relationship of Consumers‘ Perceived Hedonic Value and Behavior. Engineering Economics, 23(5), 532-540. https://doi.org/10.5755/j01.ee.23.5.1975

Larasetiati, M., \& Ali, H. (2019). Model of Consumer Trust: Analysis of Perceived Usefulness and toward Repurchase Intention in Online Travel Agent. Journal of Economics and Finance, 3(8), 
350-357. https://doi.org/10.21276/sjef.2019.3.8.5

Lee, C. W., \& Liao, C. S. (2009). The effects of consumer preferences and perceptions of Chinese tea beverages on brand positioning strategies. British Food Journal, 111(1), 80-96. https://doi.org/10.1108/00070700910924254

Lin, H. H., Wang, Y. S., \& Chang, L. K. (2011). Consumer responses to online retailer's service recovery after a service failure: A perspective of justice theory. Managing Service Quality, 21(5), 511-534. https://doi.org/10.1108/09604521111159807

Mueller Loose, S., \& Szolnoki, G. (2012). Market price differentials for food packaging characteristics. Food Quality and Preference, 25(2), 171-182. https://doi.org/10.1016/j.foodqual.2012.02.009

Munnukka, J., \& Järvi, P. (2012). The price-category effect and the formation of customer value of high-tech products. Journal of Consumer Marketing, 29(4), 293-301. https://doi.org/10.1108/07363761211237362

Murphy, A., \& Jenner-Leuthart, B. (2011). Fairly sold? Adding value with fair trade coffee in cafes. Journal of Consumer Marketing, 28(7), 508-515. https://doi.org/10.1108/07363761111181491

Park, C. (2004). Efficient or enjoyable? Consumer values of eating-out and fast food restaurant consumption in Korea. International Journal of Hospitality Management, 23(1), 87-94. https://doi.org/10.1016/j.ijhm.2003.08.001

Permana, D. (2017). Toward the best model of strategy implementation in Ind onesian Islamic banking from the lens of strategic clarity. European Research Studies Journal, 20(4), 3-15. https://doi.org/10.35808/ersj/870.

Pramatatya, V., Najib, M., \& Nurrochmat, D. R. (2004). Pengaruh Atmosfer Kedai Kopi Terhadap Emosi Dan Keputusan Pembelian Ulang. Jurnal Manajemen Dan Agribisnis, 12(2), 126-136. https://doi.org/10.17358/jma.12.2.126

Preston, C. C., \& Colman, A. M. (2000). Optimal number of response categories in rating scales: Reliability, validity, discriminating power, and respondent preferences. Acta Psychologica, 104(1), 1-15. https://doi.org/10.1016/S0001-6918(99)00050-5

Rekarti, E., \& Doktoralina, C. M. (2017). Improving Business Performance: A Proposed Model for SMEs. European Research Studies Journal, 20(3), 613-623. https://doi.org/10.35808/ersj/732

Robinson, O. C. (2014). Sampling in Interview-Based Qualitative Research: A Theoretical and Practical Guide. Qualitative Research in Psychology, 11(1), 25-41. https://doi.org/10.1080/14780887.2013.801543 
Ryu, K., Han, H., \& Jang, S. S. (2010). Relationships among hedonic and utilitarian values, satisfaction and behavioral intentions in the fast-casual restaurant industry. International Journal of Contemporary Hospitality Management, 22(3), 416-432. https://doi.org/10.1108/09596111011035981

Scarpi, D. (2006). Fashion stores between fun and usefulness. Journal of Fashion Marketing and Management: An International Journal, $10(1), \quad 7-24$. https://doi.org/10.1108/13612020610651097

Schollenberg, L. (2012). Estimating the hedonic price for Fair Trade coffee in Sweden. British Food Journal, 114(3), 428-446. https://doi.org/10.1108/00070701211213519

Shields, P.M., \& Rangarajan, N. (2013). A playbook for research methods: integrating conceptual frameworks and project management. Stillwater, OK: New Forums Press. https://en.wikipedia.org/wiki/Descriptive_research

Shuttleworth, M. (2008). Quantitative Research Design. Explorable.com: https://explorable.com/quantitative-research-design

Sorenson, D., \& Bogue, J. (2006). Modelling soft drink purchasers' preferences for stimulant beverages. International Journal of Food Science and Technology, 41(6), 704-711. https://doi.org/10.1111/j.1365-2621.2005.01139.x

Tasurru, H. H., \& Salehudin, I. (2014). Global Brands and Consumer Ethnocentrism of Youth Soft Drink Consumers in Greater Jakarta, Indonesia. ASEAN Marketing Journal, 6(2), 77-88. https://doi.org/10.21002/amj.v6i2.4212

Ting, H., \& Thurasamy, R. (2016). What matters to infrequent customers: a pragmatic approach to understanding perceived value and intention to revisit trendy coffee café. SpringerPlus, 5(1), 111. https://doi.org/10.1186/s40064-016-2259-5

Topaloğlu, C. (2012). Consumer Motivation and Concern Factors for Online Shopping in Turkey. Asian Academy of Management Journal, 17(2), 1-19.

Torlak, N. G., Demir, A., \& Budur, T. (2019). Impact of operations management strategies on customer satisfaction and behavioral intentions at café-restaurants. International Journal of Productivity and Performance Management. https://doi.org/10.1108/IJPPM-01-2019-0001

Underwood, R. L. (2003). The Communicative Power of Product Packaging: Creating Brand Identity via Lived and Mediated Experience. Journal of Marketing Theory and Practice, 11(1), 62-76. https://doi.org/10.1080/10696679.2003.11501933

Van Den Heuvel, F. P., de Langen, P. W., van Donselaar, K. H., \& Fransoo, J. C. (2011). Identification 
of Employment Concentration and Specialization Areas : Theory and Application. Beta Working Paper, 354(August), 26p. https://doi.org/10.1002/agr

Vijaranakorn, K., \& Shannon, R. (2017). The influence of country image on luxury value perception and purchase intention. In Journal of Asia Business Studies (Vol. 11, Issue 1). https://doi.org/10.1108/JABS-08-2015-0142

Wang, E. S. T. (2013). The influence of visual packaging design on perceived food product quality, value, and brand preference. International Journal of Retail and Distribution Management, 41(10), 805-816. https://doi.org/10.1108/IJRDM-12-2012-0113

Wang, E. S. T. (2015). Effect of food service-brand equity on consumer-perceived food value, physical risk, and brand preference. British Food Journal, 117(2), 553-564. https://doi.org/10.1108/BFJ-09-2013-0260

Wang, E. S. T., \& Yu, J. R. (2016). Effect of product attribute beliefs of ready-to-drink coffee beverages on consumer-perceived value and repurchase intention. British Food Journal, 118(12), 2963-2980. https://doi.org/10.1108/BFJ-03-2016-0128

Weafer, J., Burkhardt, A., \& de Wit, H. (2014). Sweet taste liking is associated with impulsive behaviors in humans. Frontiers in Behavioral Neuroscience, 8(JUNE), 1-6. https://doi.org/10.3389/fnbeh.2014.00228

Woodruff, R. B. (1997). Marketing in the 21st Century Customer Value: The Next Source for Competitive Advantage. Journal of the Academy of Marketing Science, 25(3), 256-256. https://doi.org/10.1177/0092070397253006

Yoon Kin Tong, D., fa Tong, X., \& Yin, E. (2012). Young consumers' views of infused soft drinks innovation. Young Consumers, 13(4), 392-406. https://doi.org/10.1108/17473611211282635

\section{Thank-you Note}

Hamdan has obtained his Bachelor's (2015), and Master (2017) degrees in Mercu Buana University Jakarta-Indonesia in the Faculty of Economics and Business. He has been a lecturer since September 2017 at the Mercu Buana University. Focus of this research is the intention to behave in consuming coffee. Researcher would like to express their deepest gratitude to the University of Mercu Buana Research Center for funding this research. 